\title{
Pest scenario in rice in eastern Uttar Pradesh
}

\author{
KUMUD SINGH ${ }^{1}$, V. PRASAD ${ }^{1}$, SAURABH DIXIT ${ }^{1}$ AND SAURABH VERMA* \\ Krishi Vigyan Kendra, Pilkhi, Halderpur, MAU (U.P.) INDIA \\ ${ }^{1}$ Crop Research Station (N.D.U.A. and T.), MASODHA (U.P.) INDIA
}

\section{ARITCLE INFO}

Received : 02.02 .2016

Accepted : 21.03.2016

\section{KEY WORDS :}

Rice, Survey, Insect-Pests, Pesticides

\begin{abstract}
A survey was conducted during July to December 2013 -2015 on the insect-pests and diseases incidence in rice eastern Uttar Pradesh of India. The crop is infested by many insect-pests which play a significant role in rice production. Insect-pests infest all parts of the plant at all growth stages, and a few transmit viral diseases such as leafhoppers and plant hoppers. In rice ecosystem some defender viz., dragon fly, spiders and praying mentis also were noticed. During the survey it was observed that the leaf folder and stem borer were found to be at significance level while Insect-pests as gall midge, gundhi bug, rice hispa, green leaf hopper, brown plant hopper, grasshopper etc. were also found at Rice field. Besides insectpests several diseases were noticed like root-rot,brown rot, and sheathblight. A large number of insecticides have been tried for insect-pests management; indiscriminate use of pesticides has led to severe ecological consequences, residues in consumable products and ultimately resistance to the pesticides. The increasing concern for environmental safety and global demands for pesticide residue free food evoked keen interest in pest control through eco-friendly methods.
\end{abstract}

How to view point the article : Singh, Kumud, Prasad, V., Dixit, Saurabh and Verma, Saurabh (2016). Pest scenario in rice in eastern Uttar Pradesh. Internat. J. Plant Protec., 9(1) : 297-300. 